\title{
Implementasi Multiple Honeypot dengan Raspberry Pi dan Visualisasi Log Honeypot mengunakan ELK Stack
}

\author{
Ilfan Arif Romadhan*1, Syaifudin ${ }^{2}$, Denar Regata Akbi ${ }^{3}$ \\ 1,2,3 Teknik Informatika/Universitas Muhammadiyah Malang \\ ilfanarif@outlook.com¹, saifuddin@umm.ac.id ${ }^{2}$, dnarregata@umm.ac.id ${ }^{3}$
}

\begin{abstract}
Abstrak
Perlindungan terhadap keamanan jaringan merupakan hal yang sangat penting untuk dilakukan. Mengingat kemudahan dalam mengakses jaringan memungkinkan adanya gangguan dari pihak yang ingin menyerang, merusak, bahkan mengambil data penting. Honeypot memang tidak menyelesaikan masalah pada keamanan jaringan, namun honeypot membuat penelitian tentang serangan menjadi lebih sederhana dengan konsep yang mudah untuk dimengerti dan dimplementasikan. Penelitian ini menerapkan beberapa honeypot menggunakan Raspberry pi dan ELK stack untuk monitoring hasil yang didapatkan oleh honeypot. Tujuan dari penelitian ini untuk merancang sistem yang mampu mendeteksi serangan pada jaringan menggunakan honeypot. Raspberry pi digunakan sebagai sensor honeypot untuk pemantauan ancaman keamanan terbukti hemat biaya dan efektif menggantikan komputer desktop. ELK stack memudahkan pemusatan data dari berbagai sumber dan membuat analisis log yang awalnya rumit untuk dianalisis menjadi lebih menarik.
\end{abstract}

Kata Kunci: Keamanan jaringan, Multiple Honeypot, Raspberry Pi, ELK Stack

\begin{abstract}
Protection of network security is very important to do. Given the ease in accessing the network allows for interference from parties who want to attack, destroy, and even retrieve important data. Honeypot does not solve the problem on network security, but the honeypot makes research about attacks become simpler with concepts that are easy to understand and implement. This research applies some honeypot using Raspberry pi and ELK stack for monitoring result obtained by honeypot. The purpose of this research is to design a system capable of detecting attacks on a network using a honeypot. Raspberry pi is used as a honeypot sensor for monitoring proven cost-effective and cost-effective security threats to replace desktop computers. The ELK stack facilitates the convergence of data from multiple sources and makes log analysis initially complex for analysis to be more interesting.
\end{abstract}

Keywords: Network Security, Multiple Honeypot, Raspberry Pi, ELK Stack

\section{Pendahuluan}

Seiring meningkatnya ilmu pengetahuan dan perkembangan teknologi informasi, akses data dalam jaringan menjadi sangat mudah. Salah satu kemudahan dalam teknologi pada saat ini adalah internet, orang sangat bergantung pada internet untuk menyebarkan informasi yang berharga [1]. Di sisi lain, karena ketergantungan yang tinggi pada internet, beberapa orang memanfaatkan kelemahan internet untuk memberikan gangguan kepada pengguna lainya.

Gangguan terjadi karena adanya pihak yang ingin menyerang, merusak, bahkan mengambil data-data penting. Gangguan tersebut umumnya diketahui dari gejala aneh yang terjadi. Kurangnya informasi tentang penyerang seperti siapa yang menyerang, mengapa mereka menyerang, bagaimana mereka menyerang, dan kapan serangan dilakukan, menjadi masalah yang patut untuk dicermati.

Untuk menangani hal tersebut, dibutuhkan alat bantu untuk mendeteksi serangan yang masuk ke dalam jaringan. Salah satu alat bantu dalam keamanan jaringan yang bisa digunakan adalah honeypot. Honeypot merupakan sistem yang sengaja digunakan dengan harapan untuk diserang dan dieksploitasi [2]. Honeypot mempunyai nilai tambah dalam penelitian untuk mempelajari ancaman dan resiko keamanan jaringan. Administrator dapat menganalisa aktivitas penyerang menggunakan honeypot. Secara umum, honeypot dibagi menjadi tiga tingkat, yaitu 
low interaction, medium interaction dan high interaction. Semakin tinggi tingkat interaksi pada honeypot, maka semakin besar data yang ditangkap dan semakin besar juga resiko yang diterima [3].

Biasanya honeypot diimplementasikan menggunakan satu komputer desktop atau lebih, namun dalam penelitian ini honeypot akan dipasang pada raspberry pi. Keuntungan menggunakan raspberry pi antara lain mempunyai harga yang relatif lebih murah dan mengkonsumsi daya yang lebih sedikit daripada menggunakan komputer desktop [4]. Raspberry pi dapat digunakan sebagai sensor honeypot untuk pemantauan keamanan jaringan menggantikan komputer desktop pada umumnya [5]. Selain itu, raspberry pi mudah disesuaikan, dan bisa diletakkan dimana saja karena ukurannya yang cukup kecil.

Seiring dengan sulitnya menganalisis log yang dihasilkan oleh honeypot, maka dibutuhkan alat visualisasi untuk mempermudah dalam menganalisis log honeypot. Dalam penelitian ini, hasil serangan honeypot divisualisasikan menggunakan ELK stack, dimana ELK stack ini adalah kombinasi dari elasticsearch, logstash dan kibana [6].

\subsection{Sumber log}

Dalam penelitian ini log didapatkan dari beberapa honeypot yang diimplementasikan pada raspberry pi. Honeypot tersebut terdiri dari dionaea, suricata, dan cowrie.

1. Dionaea, honeypot yang mengemulasi layanan untuk menangkap malware dengan target protokol seperti Server Message Block (SMB) [7]. Honeypot dionaea menjebak eksploitasi malware melalui kerentanan yang sengaja dibuka untuk diserang, tujuan utamanya adalah mendapatkan salinan malware [8].

2. Suricata, honeypot yang mampu mendeteksi Intrusion Detection System (IDS), Intrusion Prevention System (IPS), Network Security Monitoring (NSM) dan Packet Capture (PCAP). Di buat Open Information Security Foundation (OISF) pada tahun 2009 [9].

3. Cowrie, medium interaction honeypot yang dikembangkan oleh Michel Oosterhof pada tahun 2015. Cowrie bertujuan untuk mencatat serangan brute force dan interaksi yang dilakukan oleh penyerang [10]

4. Raspberry pi, komputer single-board yang dikembangkan oleh raspberry pi Foundation di Inggris. Komputer single-board ini mempunyai biaya lebih murah, sering digunakan dalam bidang akademis, penelitian, dan sistem embedded [11].

\subsection{Manajemen log}

Dalam penelitian ini manajemen log yang dihasilkan oleh honeypot menggunakan ELK stack. ELK stack merupakan platform manajemen dan analisis log yang komplet. Analisis log membantu dalam mendeteksi pelanggaran keamanan, penyalahgunaan aplikasi, serangan berbahaya, dan sebagainya [6]. ELK stack mempunyai beberapa unsur, antara lain:

1. Elasticsearch, mesin pencari yang berkemampuan dalam pencarian dan analisis data secara realtime. Elasticsearch mempunyai beberapa fitur seperti pencarian multibahasa, geolocation, autocomplete, JSON dan RESTful API yang memudahkan elasticsearch dalam mengelola data.

2. Logstash membantu dalam membangun jaringan pipeline yang dapat memusatkan pengolahan data. Menggunakan berbagai plugin input dan output untuk memudahkan dalam parsing dan memproses format yang berbeda dalam skala besar.

3. Kibana, memvisualisasikan data yang tersimpan pada cluster elasticsearch. Kibana menyediakan antarmuka berbasis browser yang memudahkankan dalam membuat dashboard dengan cepat. Kibana menyajikan data dalam bentuk histogram, geomaps, diagram lingkaran, grafik, tabel, dan lain-lain.

4. Filebeat, plug in logstash yang bertugas sebagai agen pada server sumber untuk mengirim data ke ELK stack. Filebeat menggantikan plug in logstash yang lama yaitu logstash forwarder atau lumberjack [12].

\section{Metode Penelitian}

\subsection{Skema Sistem}

Skema ini menjelaskan rancangan secara garis besar tentang bagaimana cara kerja dari sistem yang dibuat. Pada Gambar 1 dapat dilihat skema yang telah dirancang oleh penulis. 

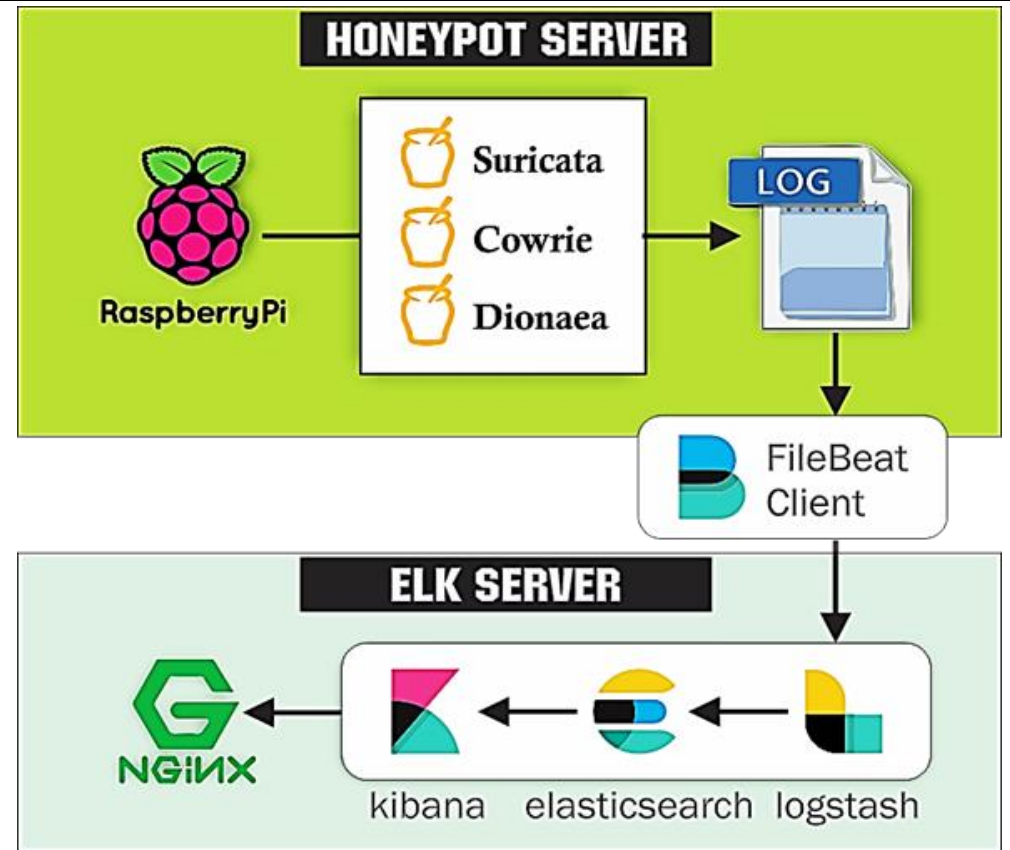

Gambar 1. Skema Sistem

Dalam skema di atas menggambarkan perangkat keras, perangkat lunak, dan alur dari sistem secara umum. Terdapat tiga honeypot yang dipasang pada raspberry pi, honeypot akan menghasilkan log yang berisi catatan serangan. ELK server akan mengolah log dari honeypot dan menampilkanya dalam bentuk visualisasi yang menarik.

Alur kerja dari sistem yaitu ketika terjadi serangan maka honeypot akan menangkap serangan dan mencatat serangan tersebut. Data serangan yang didapatkan akan disimpan dalam log masing-masing honeypot. Data log dari honeypot dikirim ke ELK server menggunakan plug in filebeat. Log akan diolah ELK stack untuk divisualisasikan dan akan ditampilkan menggunakan dashboard pada web browser.

\subsection{Arsitektur Honeypot Server}

Pada arsitektur ini raspberry pi sebagai server yang digunakan untuk menjalakan honeypot. Ditunjukkan Gambar 2 dari arsitektur honeypot server.

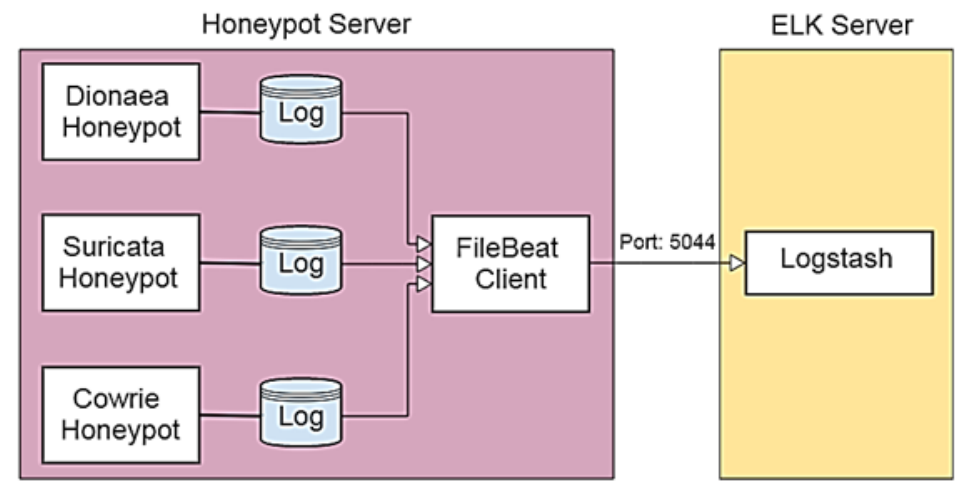

Gambar 2. Arsitektur Honeypot Server

Pada honeypot server terdapat tiga honeypot yang berbeda. Honeypot terserebut antara lain suricata yang bekerja dengan cara monitoring jaringan, mencatat paket pada lalu lintas, IDS, dan IPS. cowrie bekerja dengan cara mencatat serangan brute force dan interaksi yang dilakukan oleh penyerang, dan dionaea bekerja dengan cara menjebak eksploitasi malware melalui kerentanan yang sengaja dibuka untuk diserang. Masing-masing honeypot menghasilkan log 
untuk dianalisis. Log tersebut akan dikirim dari honeypot server menuju ELK server menggunakan filebeat client dengan port 5044.

Ditunjukkan pada Tabel 1 beberapa port yang dibuka oleh masing-masing honeypot untuk mendeteksi kejadian dalam jaringan.

Tabel 1. Port yang Dibuka Honeypot

\begin{tabular}{clc}
\hline $\begin{array}{c}\text { Jenis } \\
\text { Honeypot }\end{array}$ & \multicolumn{1}{c}{ Port } & \multicolumn{1}{c}{ Tingkat Interaksi } \\
\hline Dionaea & $42,53,123,80,443,5060 / 5060 / 5061,21,69$, & Rendah \\
& $445,1433,3306$ & \\
& $80,81,82,83,84,85,86,87,88,89,311,383$, & \\
& $591,593,631,901,1220,1414,1741,1830$, & \\
& $2301,2381,2809,3037,3057,3128,3702,4343$, & \\
Suricata & $4848,5250,6080,6988,7000,7001,7144,7145$, & Rendah \\
& $7510,7777,7779,8000,8008,8014,8028,8080$, & \\
& $8085,8088,8090,8118,8123,8180,8181,8222$, & \\
& $8243,8280,8300,8500,8800,8888,8899,9000$, & \\
& $9060,9080,9090,9091,9443,9999,10000$, & Menengah \\
\hline Cowrie & $11371,34443,34444,41080,50002,55555$ & \\
\hline
\end{tabular}

\subsection{Arsitektur ELK Server}

Pada arsitektur ini ELK server akan digunakan untuk mengolah log yang dihasilkan honeypot menjadi visualisasi yang menarik. Ditunjukkan pada Gambar 3 arsitektur ELK server. Logstash akan menerima log yang dikirim dari plug in filebeat menggunakan port 5044. Logstash mengumpulkan data tersebut kemudian dikirim menuju elasticsearch menggunakan port 9200. Pada elasticsearch data akan diolah dan dianalisis untuk ditampilkan dalam visualisasi menggunakan kibana. Kibana berjalan pada port 5601 dan berinteraksi dengan data yang tersimpan dalam indeks elasticsearch. Menggunakan kibana akan mempermudah dalam memvisualisasikan data dalam berbagai grafik, tabel, dan lain-lain. Pada penelitian ini akses kibana menggunakan localhost, jadi untuk memungkinkan akses dari eksternal menggunakan proxy nginx. Selain itu, nginx akan menggunakan file htpasswd. users untuk mengkonfirmasi pengguna yang diperbolehkan mengakses kibana.

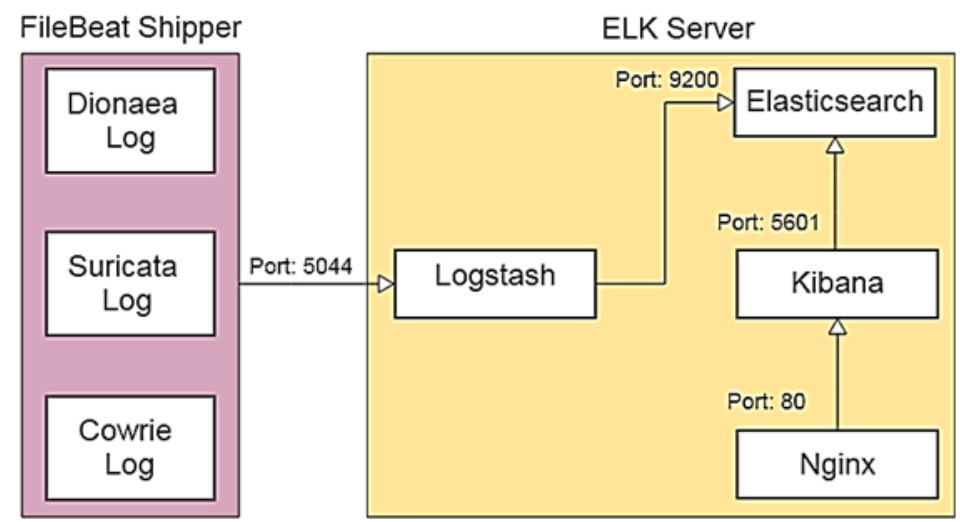

Gambar 3. Arsitektur ELK Server

\subsection{Rancangan Pengujian}

Pengujian pada penelitian ini menggunakan metode black box. Pengujian ini dilakukan untuk membuktikan sejauh mana kesesuaian sistem yang dibangun bekerja dengan fungsionalitas dan tujuan perancangan. Adapun beberapa rancangan pengujian didasarkan terhadap beberapa hal, antara lain apakah sistem yang dirancang mampu menangkap dan memberikan peringatan serangan, hasil yang ditangkap oleh honeypot, dan visualisasi log dari honeypot yang ditampilkan oleh ELK stack. 


\subsubsection{Skenario Serangan Honeypot}

Simulasi serangan dilakukan dengan dua tahap dengan cara menyerang server honeypot. Serangan yang dilakukan dapat dilihat pada, pengujian serangan ini dilakukan dengan cara menyerang server honeypot secara langsung. Adapun pada serangan tahap pertama, penulis yang akan bertindak sebagai penyerang dalam pengujian ini, ditunjukkan pada Gambar 4.

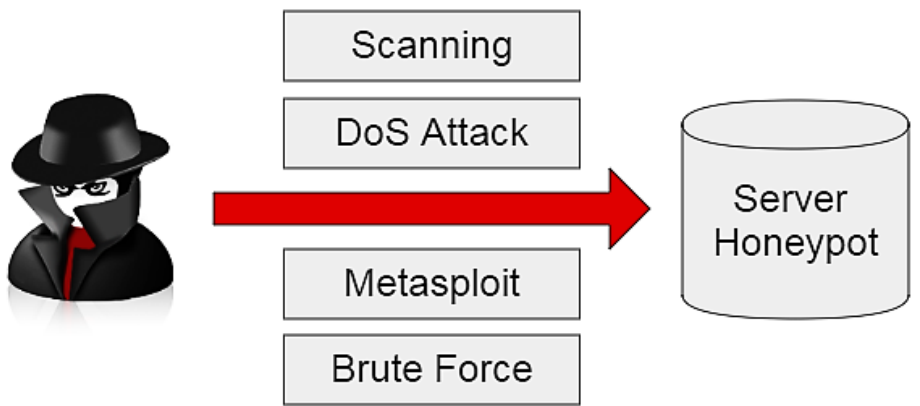

Gambar 4. Skenario Serangan Honeypot

Dalam simulasi serangan terdapat empat cara yang dilakukan antara lain scanning, serangan DoS, metasploit, dan serangan brute force. Ditunjukkan pada Tabel 2 penjelasan dari serangan yang dilakukan.

Tabel 2. Perintah Simulasi Serangan Honeypot

\begin{tabular}{|c|c|}
\hline Opsi Serangan & Deskripsi \\
\hline $\begin{array}{l}\text { Scanning menggunakan } \\
\text { Nmap }\end{array}$ & $\begin{array}{l}\text { IP target serangan: } 192.168 .1 .6 \\
\text { IP penyerang: 192.168.1.5 } \\
\text { Perintah : } \\
\text { nmap-Su-St -A -O 192.168.1.2 }\end{array}$ \\
\hline $\begin{array}{l}\text { Serangan Brute force } \\
\text { menggunakan Hydra }\end{array}$ & $\begin{array}{l}\text { IP target serangan: } 192.168 .1 .6 \\
\text { IP penyerang: } 192.168 .1 .5 \\
\text { Perintah 1: } \\
\text { Hydra -L nama.txt }-\mathrm{P} \text { passwd.txt } 192.168 .1 .6 \mathrm{ssh} \\
\text { Perintah 2: } \\
\text { Hydra -L nama.txt }-\mathrm{P} \text { passwd.txt } 192.168 .1 .6 \mathrm{ftp}\end{array}$ \\
\hline $\begin{array}{c}\text { Serangan DoS } \\
\text { menggunakan Low Orbit } \\
\text { Ion Cannon (LOIC) }\end{array}$ & $\begin{array}{l}\text { IP target serangan: } 192.168 .1 .6 \\
\text { IP penyerang: } 192.168 .1 .5 \\
\text { Perintah yang dilakukan yaitu flooding dengan IP tujuan } \\
\text { 192.168.1.6, port } 445 \text {, metode TCP, dan jumlah flood } \\
1.000\end{array}$ \\
\hline $\begin{array}{c}\text { Serangan MS17-10 } \\
\text { menggunakan metasploit }\end{array}$ & $\begin{array}{l}\text { IP target serangan: } 192.168 .1 .20 \\
\text { IP penyerang: 192.168.1.19 } \\
\text { Perintah : } \\
\text { msf exploit(eternalblue_doublepulsar) > } \\
\text { use auxiliary/scanner/smb/smb_ms17_010 }\end{array}$ \\
\hline
\end{tabular}

Serangan tahap kedua dilakukan hari pada hari senin tanggal 9 oktober 2017 di kelas keamanan jaringan dari jam pertama s.d. jam ketiga. Skenario yang dilakukan yaitu mahasiswa yang mengikuti kuliah tersebut melakukan scanning untuk mencari server yang membuka banyak port, kemudian melakukan serangan brute force pada server tersebut.

\subsubsection{Pengujian Performa}

Pengujian performa dilakukan untuk mengetahui performa sistem ketika dilakukan penyerangan pada honeypot dan performa sistem ketika pengiriman log dari server honeypot menuju server ELK. Parameter yang diuji adalah penggunaan sumber daya memori dan CPU. Untuk mendapatkan informasi performa tersebut yang sedang diuji, penulis menggunakan perangkat lunak glances. Perangkat lunak tersebut bekerja dengan memberikan informasi tentang seberapa besar penggunaan CPU dan memori pada saat menerima serangan. 


\section{Hasil Penelitian dan Pembahasan}

\subsection{Pengujian Serangan Honeypot Tahap Pertama}

Dalam pengujian honeypot, dilakukan serangan terhadap masing-masing honeypot sesuai dengan rancangan yang telah dibuat. Selain itu, juga ditunjukkan hasil visualisasi dari log yang dihasilkan oleh honeypot.

\subsubsection{Scanning Nmap}

Pada tahap ini percobaan scanning yang penulis lakukan menggunakan Nmap dengan perintah nmap -sU -sT -A -O 192.168.1.6. Pada hasil scanning tersebut terdapat beberapa port yang berstatus open, port tersebut bisa digunakan penjahat sebagai celah untuk diserang. Hasil percobaan tersebut ditangkap oleh dionaea, suricata dan cowrie.

Berdasarkan percobaan dan hasil yang ditampilkan pada Gambar 5 ini, kejadian yang ditangkap oleh suricata sebanyak 3346, cowrie sebanyak 71, dan dionaea sebanyak 2053 kejadian. Suricata menangkap kejadian paling banyak pada percobaan ini.

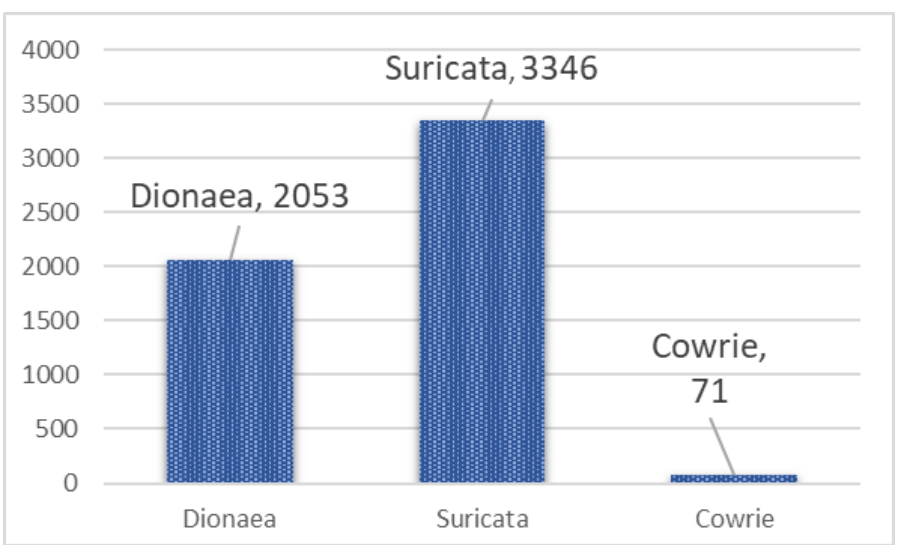

Gambar 5. Jumlah Kejadian Ditangkap Honeypot Terhadap Scanning Nmap

\subsubsection{Serangan Brute Force}

Setelah dilakukan scanning port mengunakan Nmap, terdapat port 21 dan 22 dengan status open. Biasanya port 21 digunakan FTP server untuk tukar menukar data dan SSH menggunakan port 22 yang digunakan untuk menghubungkan antara komputer satu ke komputer lainya di internet. Pada dapat ditunjukkan serangan brute force SSH yang penulis lakukan menggunakan hydra.

Kemudian percobaan serangan brute force pada port FTP yang penulis lakukan menggunakan hydra. Percobaan serangan brute force SSH dapat ditangkap oleh suricata dan cowrie, namun dionaea tidak. Sebaliknya pada percobaan serangan brute force FTP, suricata dan dionaea dapat menangkap serangan, namun cowrie tidak. Seperti ditunjukkan pada Gambar 6 berdasarkan percobaan serangan brute force pada SSH dan FTP yang dilakukan, suricata menangkap kejadian sebanyak 310, cowrie sebanyak 176, dan dionaea sebanyak 606 kejadian. Dionaea menangkap kejadian paling banyak kejadian pada serangan ini.

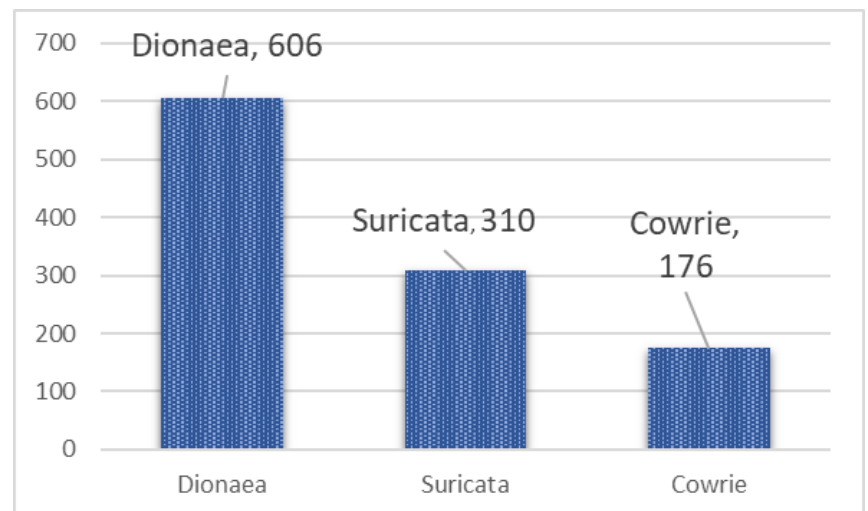

Gambar 6. Jumlah Kejadian Ditangkap Honeypot Terhadap Serangan Brute Force

REPOSITOR, Vol. 2, No. 4, April 2020: 475-484 


\subsubsection{Serangan DoS}

Serangan berikutnya yaitu serangan DoS, ditunjukkan pada Gambar 7 serangan DoS menggunakan LOIC. Serangan ini dilakukan dengan IP tujuan 192.168.1.6, port 445, metode TCP, dan jumlah flood 1.000 .

Berdasarkan percobaan tersebut kejadian yang ditangkap oleh suricata sebanyak 53 , dionaea sebanyak 428 kejadian dan cowrie tidak berhasil menangkap kejadian. Dionaea menangkap kejadian paling banyak pada serangan ini.

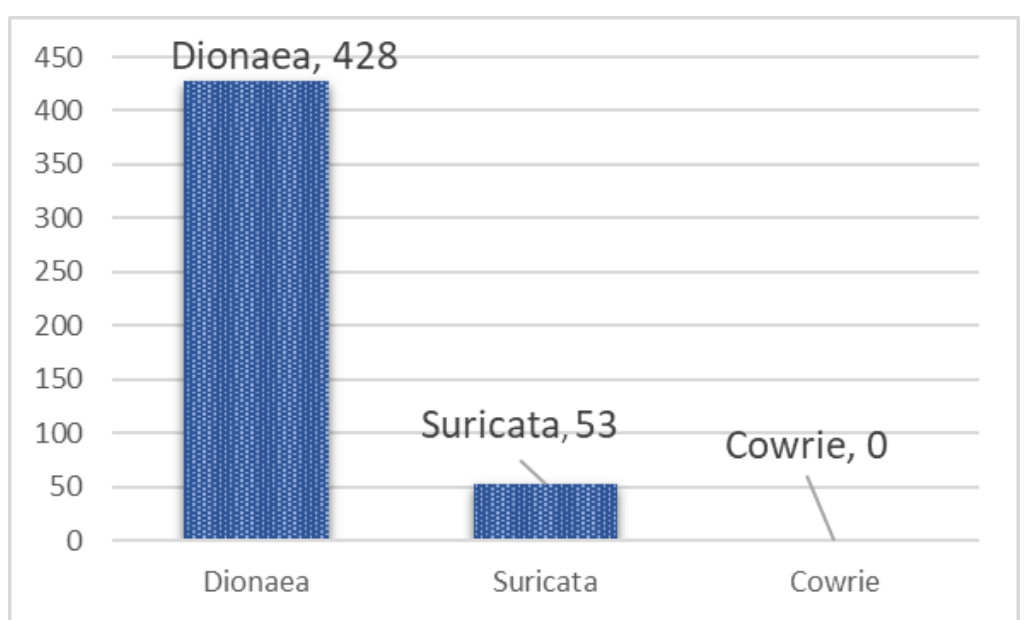

Gambar 7. Jumlah Kejadian Ditangkap Honeypot Terhadap Serangan DoS

\subsubsection{Serangan Metasploit}

Pada percobaan serangan ini dilakukan dengan cara eksploitasi yang digunakan oleh malware jenis wannacry ransomware untuk mengeksploitasi kerentanan. Serangan metasploit ini menggunakan modul SMB MS17-10. Berdasarkan percobaan tersebut kejadian yang ditangkap oleh suricata sebanyak 239, dionaea sebanyak 502 kejadian dan cowrie tidak berhasil menangkap kejadian. Ditunjukkan pada Gambar 8 dionaea menangkap kejadian paling banyak pada serangan ini.

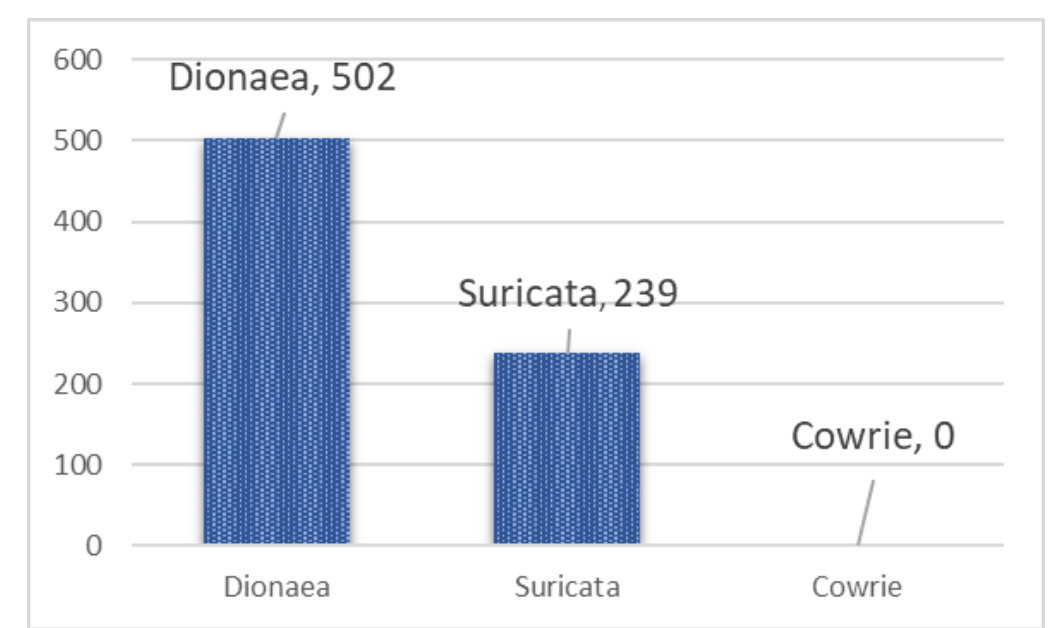

Gambar 8. Jumlah Kejadian Ditangkap Honeypot Terhadap Serangan Metasploit

\subsection{Pengujian Serangan Honeypot Tahap Kedua}

Pada tahap ini, pengujian dilakukan dengan serangan Nmap dan brute force dilakukan oleh mahasiswa yang mengikuti mata kuliah keamanan jaringan. Berdasarkan percobaan tersebut kejadian yang ditangkap oleh suricata sebanyak 73.622, dionaea sebanyak 10.744 kejadian dan cowrie sebanyak 49.922 kejadian. Ditunjukkan pada Gambar 9, suricata menangkap kejadian paling banyak pada serangan ini. 


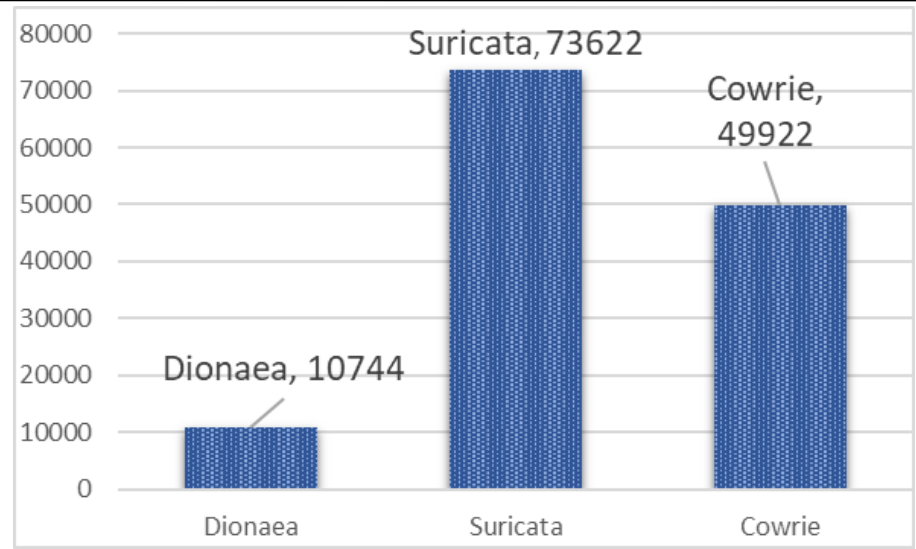

Gambar 9. Jumlah Kejadian Ditangkap Honeypot Terhadap Percobaan Serangan Pada Kelas Keamanan Jaringan

Dari hasil monitoring performa, dapat diperoleh data seperti ditunjukkan pada Tabel 3. Selama proses percobaan scanning, dionaea mengkonsumsi penggunaan CPU paling besar yaitu $32,4 \%$ dan pemakaian memori paling tinggi yaitu suricata dengan jumlah $16,9 \%$.

\begin{tabular}{ccc}
\multicolumn{3}{c}{ Tabel 3. Hasil Monitoring Sistem ketika Scanning Nmap } \\
\hline Nama Service & CPU Terpakai & Memori Terpakai \\
\hline Suricata & $7,5 \%$ & $16,9 \%$ \\
Dionaea & $32,4 \%$ & $3,0 \%$ \\
Cowrie & $23,6 \%$ & $4,1 \%$ \\
Filebeat & $15,6 \%$ & $2,6 \%$ \\
\hline
\end{tabular}

Pada saat dilakukan percobaan serangan brute force SSH, proses cowrie mengkonsumsi penggunaan CPU paling besar, yaitu 44,0\% dan pemakaian memori paling tinggi yaitu suricata dengan jumlah $16,9 \%$. Sedangkan ketika serangan brute force FTP, proses dionaea mengkonsumsi penggunaan CPU paling besar yaitu 20,2\% dan pemakaian memori paling tinggi yaitu suricata dengan jumlah 16,9\%, seperti ditunjukkan pada 4 dan Tabel 5.

Tabel 4. Hasil Monitoring Sistem ketika Serangan Brute Force SSH

\begin{tabular}{ccc}
\hline Nama Service & CPU Terpakai & Memori Terpakai \\
\hline Suricata & $5,1 \%$ & $16,9 \%$ \\
Dionaea & $0,3 \%$ & $2,7 \%$ \\
Cowrie & $44,0 \%$ & $4,1 \%$ \\
Filebeat & $11,8 \%$ & $2,0 \%$ \\
\hline
\end{tabular}

Tabel 5. Hasil Monitoring Sistem ketika Serangan Brute Force FTP

\begin{tabular}{ccc}
\hline Nama Service & CPU Terpakai & Memori Terpakai \\
\hline Suricata & $8,1 \%$ & $16,9 \%$ \\
Dionaea & $20,2 \%$ & $2,7 \%$ \\
Cowrie & $0 \%$ & $0 \%$ \\
Filebeat & $4,0 \%$ & $2,0 \%$ \\
\hline
\end{tabular}

Kemudian ketika percobaan serangan DoS menggunakan LOIC. Dari hasil monitoring pada Tabel 6, proses dionaea mengkonsumsi penggunaan CPU paling besar yaitu $73,6 \%$ dan pemakaian memori paling tinggi yaitu pada dionaea dengan jumlah $44,5 \%$.

\begin{tabular}{ccc} 
Tabel 6. Hasil Monitoring Sistem ketika Serangan LOIC \\
\hline Nama Service & CPU Terpakai & Memori Terpakai \\
\hline Suricata & $42,6 \%$ & $17,5 \%$ \\
Dionaea & $73,6 \%$ & $44,5 \%$ \\
Cowrie & $0,0 \%$ & $3,7 \%$ \\
Filebeat & $0,0 \%$ & $1,6 \%$ \\
\hline
\end{tabular}

REPOSITOR, Vol. 2, No. 4, April 2020: 475-484 
Dari hasil monitoring proses pada Tabel 7 , saat percobaan serangan metasploit, dionaea mengkonsumsi penggunaan CPU paling besar, yaitu 14,7\% dan pemakaian memori paling tinggi yaitu pada suricata dengan jumlah $16,9 \%$.

\begin{tabular}{ccc}
\multicolumn{3}{c}{ Tabel 7. Hasil Monitoring Sistem ketika Serangan Metasploit } \\
\hline Nama Service & CPU Terpakai & Memori Terpakai \\
\hline Suricata & $4,5 \%$ & $16,9 \%$ \\
Dionaea & $14,7 \%$ & $2,7 \%$ \\
Cowrie & $0,0 \%$ & $0,0 \%$ \\
Filebeat & $0,8 \%$ & $2,2 \%$ \\
\hline
\end{tabular}

Ditunjukkan pada Tabel 8 perbandingan kemampuan yang dimiliki oleh honeypot yang digunakan untuk mendeteksi kejadian dan mengungkap informasi dari berbagai jenis serangan yang dilakukan. Dengan tabel tersebut dapat diketahui perbedaan dari beberapa honeypot yang digunakan.

Tabel 8. Perbandingan Kinerja Honeypot

\begin{tabular}{ccccc}
\hline $\begin{array}{c}\text { Nama } \\
\text { Honeypot }\end{array}$ & $\begin{array}{c}\text { Jumlah } \\
\text { Peringatan } \\
\text { Keseluruhan }\end{array}$ & $\begin{array}{c}\text { Mendeteksi } \\
\text { Perangkat } \\
\text { Lunak } \\
\text { Serangan }\end{array}$ & $\begin{array}{c}\text { Mendeteksi } \\
\text { Percobaan } \\
\text { Login }\end{array}$ & $\begin{array}{c}\text { Mengungkap } \\
\text { Username/ } \\
\text { Password } \\
\text { Penyerang }\end{array}$ \\
\hline Suricata & 77.570 & Ya & Ya & Tidak \\
Dionaea & 14.333 & Tidak & Tidak & Ya \\
Cowrie & 50.169 & Tidak & Ya & Ya \\
\hline
\end{tabular}

Setelah melakukan beberapa percobaan serangan, penulis menunjukkan hasil visualisasi dari log yang diperoleh masing-masing honeypot. Ditunjukkan pada Gambar 10, sebagai contoh tampilan dari serangan yang dihasilkan oleh cowrie honeypot pada saat serangan tahap kedua.

Cowrie honeypot dapat mendeteksi semua usaha login ke server dan memberikan informasi yang sangat berharga. Informasi tersebut terdiri dari username dan password yang dilakukan oleh penyerang untuk mencoba memasuki server, sesuai dengan fungsi dari cowrie honeypot. Pada hasil pengujian ini membuktikan bahwa ELK stack dapat mengumpulkan log dari sumber yang berbeda host dan membuat analisis dari log yang awalnya rumit menjadi lebih menarik.

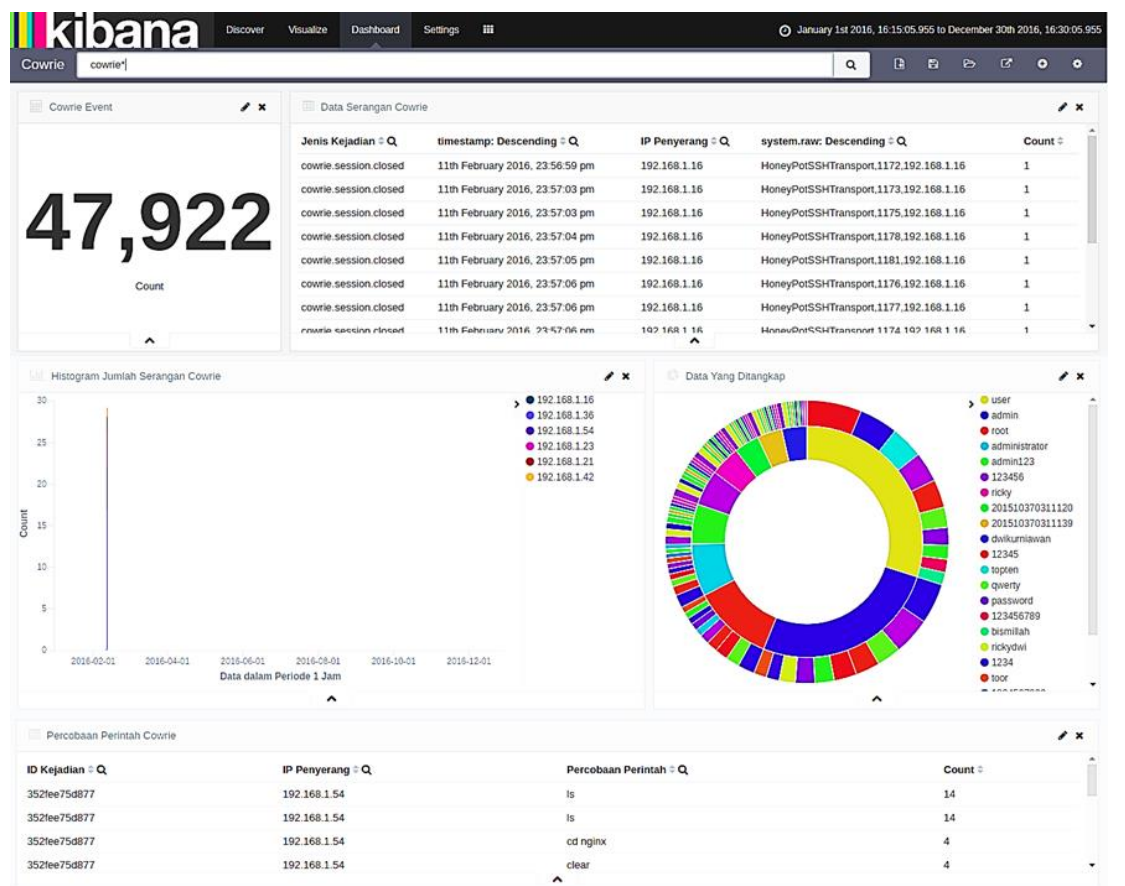

Gambar 10. Visualisasi Log Cowrie Honeypot Saat Serangan Tahap Kedua 


\section{Kesimpulan}

Salah satu tujuan honeypot adalah memberikan server palsu, dimana penyerang akan membuang-buang waktu untuk melakukan serangan. Hal ini dapat digunakan oleh administrator sistem melakukan tindakan untuk mengamankan server yang sebenarnya dari pengguna yang tidak sah. Honeypot mengumpulkan data hanya jika seseorang berinteraksi dengannya. Server honeypot akan menangkap serangan dalam jaringan sesuai dengan port yang dimiliki oleh masing-masing honeypot. Jika serangan berkomunikasi dengan port yang dibuka, maka sistem akan menangkap serangan tersebut. Honeypot memang mempunyai informasi yang sangat berharga, namun tidak langsung berguna tanpa analisis secara teliti oleh yang berpengalaman dibidang keamanan jaringan.

Logstash mempunyai plugin filter untuk memproses data berformat json, jadi tidak memerlukan pekerjaan tambahan untuk mengirim log honeypot yang berformat json dari raspberry pi menuju logstash. Menggunakan ELK stack akan memberi keuntungan untuk mencari log lebih mendalam berdasarkan timestamp. Berbagai jenis bentuk untuk visualisasi log seperti diagram, tabel, dan lain-lain sercara real time.

\section{Saran}

Penelitian ini berfokus pada bagaimana cara implementasi beberapa honeypot pada raspberry pi dan memvisualisasikan hasil log honeypot pada ELK stack. Masih banyak ditemukan kekurangan pada penelitian sehingga memungkinkan digunakan sebagai tumpuan pada pengembangan penelitian selanjutnya.

Penulis memberikan saran antara lain untuk penelitian kedepanya dapat menerapkan berbagai sensor honeypot yang baru pada raspberry pi kemudian menempatkan server honeypot berdasarkan penempatan yang sebenarnya, sehingga sistem ini sungguh-sungguh dimanfaatkan bagi pembaca yang hendak meneruskan penelitian. Hasil yang didapat oleh honeypot sangat banyak, sehingga dapat dilakukan beberapa penelitian untuk mempelajari kemampuan dan hasil yang diperoleh oleh honeypot dalam mengungkap informasi penyerang secara mendalam. Kemudian dapat dilakukan tindakan kelanjutan seperti blocking access terhadap akses ilegal.

\section{Referensi}

[1] D. K. Bhattacharyya dan J. K. Kalita, DDoS Attacks: Evolution, Detection, Prevention, Reaction, and Tolerance. CRC Press, 2016.

[2] L. Spitzner, Honeypots: tracking hackers. Boston: Addison-Wesley, 2003.

[3] R. C. Joshi dan A. Sardana, Honeypots: a new paradigm to information security. Enfield, N.H. : Boca Raton, FL: Science Publishers ; Distributed by CRC Press, 2011.

[4] S. Mahajan, A. M. Adagale, dan C. Sahare, "Intrusion Detection System Using Raspberry PI Honeypot in Network Security," Int. J. Eng. Sci., vol. 6, no. 3, hal. 2792, 2016.

[5] C. Lim, M. Marcello, A. Japar, J. Tommy, dan I. E. Kho, "Development of Distributed Honeypot Using Raspberry Pi," 2014.

[6] S. Chhajed, Learning ELK stack: build mesmerizing visualizations, and analytics from your logs and data using Elasticsearch, Logstash, and Kibana. 2015.

[7] C. Moore dan A. Al-Nemrat, "An Analysis of Honeypot Programs and the Attack Data Collected," in International Conference on Global Security, Safety, and Sustainability, 2015, hal. 228-238.

[8] "Dionaea Documentation." [Daring]. Tersedia pada: http://dionaea.readthedocs.io. [Diakses: 25-Jul-2017].

[9] J. S. White, T. Fitzsimmons, dan J. N. Matthews, "Quantitative analysis of intrusion detection systems: Snort and Suricata," SPIE Def. Secur. Sens., hal. 875704-875704, 2013.

[10] M. Oosterhof, "Cowrie Honeypot," Security Intelligence. [Daring]. Tersedia pada: http://www.micheloosterhof.com/cowrie/. [Diakses: 23-Jun-2017].

[11] A. Pajankar, Arush Kakkar, Matthew Poole, TotalBoox, dan TBX, Raspberry Pi: Making Amazing Projects Right from Scratch! Packt Publishing, 2016.

[12] J. Turnbull, The Logstash Book. James Turnbull, 2013. 